\title{
A Narrative Analysis of the Political Economy Shaping Policy on Child Nutrition in India
}

\section{Nicholas Nisbett}

This is the peer reviewed version of the following article: Nisbett, Nicholas. "A Narrative Analysis of the Political Economy Shaping Policy on Child Undernutrition in India." Development and Change 48.2 (2017): 312-38, which has been published in final form at https://doi.org/10.1111/dech.12297

This article may be used for non-commercial purposes in accordance with Wiley Terms and Conditions for Use of Self-Archived Versions.

Please use the full reference in citation:

\begin{abstract}
This article examines two narratives on the subject of child undernutrition in India espoused by competing sides of the policy elite. It argues that undertaking narrative policy analysis in a structured fashion helps to elucidate a clearer sense of the underlying positions within this important area of development discourse. India's high rates of child undernutrition have become a battleground of positions on the country's growth trajectory, revealing of the wider assumptions, ideologies and manifestations of power of the various actors espousing particular positions. Recent debates have brought into focus not only the contestation of various causalities and remedies, but also the politics of measurement, data and their interpretation. The results of this analysis are relevant elsewhere in their illumination of the politically public nature of technocratic debates on nutrition and the way in which this public discourse extends beyond the immediate topic to wider ideological divisions and assumptions on growth, equity and recent history.
\end{abstract}




\section{Acknowledgements}

I am grateful to the two anonymous reviewers and the editors of Development and Change for earlier comments on this manuscript. I would like to thank Sabine Mosner, for encouraging my belief that narratives matter in policy.

\section{INTRODUCTION}

To talk of a national narrative, a political narrative or a policy narrative in a broad sense has become common in the media, public sphere and academia in many countries. Politicians and the media discuss refashioning, shaping and seizing the political narrative; bureaucrats are tasked explicitly with writing policy narratives and 'core scripts'; and political actors are commonly taken to task for failing to articulate a coherent narrative - whether to describe an overall desired political trajectory (which resonates with voters) or in the face of a particular policy problem. Understanding, comparison and analysis of competing narratives on a particular political or policy issue often take place both in media commentary and some academic literature on this basis of a story towards (or how to achieve) a particular desired end, which resonates. Such analysis might consider the narrative's own internal logic and consistency, and its impact both internally and externally in 'framing' a particular policy issue and setting the boundaries of public, political and media discussion of a topic. Without complicating the analytical tool box too much, such analysis can be very useful in understanding the role of narrative in political strategy and policy processes at a country or global level.

In parallel, a rich body of academic literature on the topic of narrative has continued to be developed and to be applied from diverse disciplinary and methodological perspectives to a diverse range of topics and contexts — including public policy (Riessman, 2008: 4-7). The so-called 'narrative turn' in the social sciences can be traced back to the influence of literary theory and linguistics on the social and human sciences from the 1960s onwards. It has been mostly popular towards the more interpretive, social-constructivist or poststructuralist ends of these disciplines, but more recently within the political science field of policy analysis it has been linked to more structuralist/positivist approaches and applied systematically in statistical correlational studies (Jones and Mcbeth, 2010; Mcbeth et al., 2007; Shanahan et al., 2013). Both 'narrative analysis' and 'narrative policy analysis' encompass a wide range of potential methods — ranging from simple (but often rewarding) thematic analysis of the stories people tell to complex and codified deconstructions and 
analysis of speech and 'narrative-like' public statements, their underlying structures, content and the context in which they are delivered or 'performed'.

This article reviews current approaches to narrative analysis and its application to policy narratives, and applies a number of these approaches to the study of narratives around the topic of undernutrition in India. The focus is on a specific case reported widely in the English language media in India and in prominent global media in the US and the UK. The purpose is twofold: first, this article makes the case for a fuller appreciation of the role that narrative analysis can play in enhancing understanding of wider development discourse and public health policy processes in development contexts. It argues that whilst the first common-sense approach to narrative is good enough, there are some real benefits in borrowing from more nuanced and structured approaches to narrative analysis that have been developed in wider policy studies. Second, it attempts to demonstrate this utility in considering both the context and effects of two prominent and competing narratives linking child nutritional status/growth with economic growth and poverty in India. The main empirical section of this article explores the unfolding of these policy narratives and employs a number of the tools available to the analyst of policy narratives to help uncover what the narratives, narrators and the context of their narration reveal in terms of their underlying assumptions, strategies and historical trajectories.

\section{UNDERSTANDING NARRATIVE (POLICY) ANALYSIS}

\section{Why Narrative Analysis?}

The Oxford dictionaries define narrative as 'a spoken or written account of connected events, a story', and sub-defines it in terms familiar in sociological analysis as 'a representation of a particular situation or process in such a way as to reflect or conform to an overarching set of aims or values'. ${ }^{1}$ As with the common-sense definition applied at the beginning of this article, narrative analysis as applied to policy need not stray too far from a simple approach which looks at the power of stories to persuade, and seeks, through further analysis of context, to uncover their underlying assumptions and power structures. Emery Roe's work in

\footnotetext{
${ }^{1}$ See https://en.oxforddictionaries.com/definition/narrative (accessed 12 December 2016).
} 
environmental policy has been influential in this vein and has been adapted to many other policy fields. Within critical public health and development studies, for example, Leach and Scoones (2013) recently summarized Roe's (1994) approach to analysing policy narratives as being 'simple storylines describing a policy problem, why it matters and to whom, and what should be done about it, that drive and justify interventions promoted by, or suiting the political interests, of certain groups' (Leach and Scoones, 2013: 10-11). They go on to consider the way narratives shape the use of different modelling approaches to zoonotic diseases. Given that our understanding of emergent zoonotic diseases places us at the boundaries of current virological, epidemiological and socio-cultural knowledge in this area, this is a useful example. It illustrates well the contention of Roe that 'bureaucratic stories and narratives are ... the way public managers, government policymakers and politicians articulate and, if they can, structure the ambiguities attached to important policy issues' (Roe, 1989: 262-63). That narrative policy analysis can be particularly useful for the analysis of such 'wicked problems' that is, those not lending themselves to resolution by established/accepted scientific facts, is advocated by others (Mcbeth et al., 2007: 89). These authors describe how narrative theory contributes to policy analysis in allowing the foregrounding of the power and values of actors involved in a conflict over a particular 'wicked problem' and how these values are framed strategically (ibid.).

Understanding narratives as both frames expressing moral values and as means of making sense of a world at the edges of available knowledge taps in to a rich body of analysis on narrative reaching back to Aristotle's first queries into the nature of myth telling and the associated rhetorical devices of the myth teller (Riessman, 2008: 4). 'Causal narratives are one of the basic human ways to apprehend the often complex world' (Berg and Hukkinnen, 2011: 153). 'Attention to stories' therefore 'demands attention to the social actors who tell them' (Dodge et al., 2005: 290) — as actors provide both their version and their interpretation of events at the same time (Feldman et al., 2004: 148).

Good narrative analysis simply tries to surface intended meaning and values and the strategies used to impart these, to consider implicit or tacit knowledge bound up within them, and to deconstruct wider norms and beliefs embedded in narratives (Berg and Hukkinnen, 2011; Dodge et al., 2005; Feldman et al., 2004; Riessman, 2008). As Riessman (2008: 13) observes, '[A] good narrative analysis prompts the reader to think beyond the surface of the text, and there is a move towards a broader commentary'. 


\section{Narrative and Discourse}

Narratives have multiple effects on both the narrator and the audience - conveying meaning and acting to persuade, but also helping surface tacit or practical knowledge on a subject. As a collection, narratives are constitutive of communities of knowledge that become accepted societal norms and beliefs (Dodge et al., 2005: 290-1). Narratives therefore can be seen as a precursor to the creation of discourse.

Discourse in the Foucauldian sense most commonly used in the critical social sciences describes the way in which power operates diffusively in the connections between acceptable (scientific) knowledge paradigms, dominant ideological assumptions and the self-discipline of citizens socialized to conduct themselves according to acceptable forms of knowledge and practice (for an introduction see Rabinow, 1991). Such approaches have been applied from the mid-1990s onwards in the work of scholars such as James Ferguson and Akhil Gupta in classic ethnographies treating development itself as a discursive field worthy of critical study. As with narrative analysis, such works help elucidate the interests and power that lie behind a wide range of development ideologies, bodies of knowledge and evidence, and technical approaches and practices (for further works and introductions see Ferguson, 1994; Gardner and Lewis, 2015; Goldman, 2005; Gupta, 2013; Mosse, 2004).

Stories are everywhere in development, told and retold in every setting from the grassroots activist to a government policy or a UN document. The approaches to narrative analysis outlined here provide a set of tools and concepts to excavate the wider intentions, meanings and shared understanding caught within the narratives of the actors and organizations involved in development politics and policy. Paying analytical attention to both narrative and discourse enhances our ability to understand the discursive effects of narrative and the narrated characteristics of certain discourses.

\section{Approaching Narrative Policy Analysis}

At its simplest a narrative is a story - a temporal sequence of events, usually with a central character or characters; a plot linking events, settings and characters together. A sense of causality or moral resolution is usually provided explicitly or implicitly in the narrator's explanation; the narrative content or its structure (Dodge et al., 2005; Feldman et al., 2004; Jones and Mcbeth, 2010; Shanahan et al., 2013). Extending further the moral nature of 
narrative, some definitions of narrative policy require a central hero, villain or victim (Shanahan et al., 2013). Analysts distinguish between stories and non-stories; with nonstories (i.e. statements or arguments lacking the key elements of narrative described here) often being articulated in the same context as narrative, but lacking the same impact; only reinforcing the dominant narrative as they become incorporated into a 'meta-narrative' (Roe, 1989).

Most analysts also stress the specifically strategic or intentional nature of narrative people don't simply tell stories, but do so to achieve some specific end — including conveying a particular belief; establishing 'facts' or facts of an event; shaping the wider perception of a particular issue; or helping shape their own understanding of an event. This is often in dialogue with an audience. To achieve this within policy narratives, ie those intended to advocate or explicate a particular policy stance - (Shanahan et al., 2013), narrators will include both narrative elements which resonate with the expectations of the audience (plot/characters/moral etc.) and also a number of narrative strategies - 'the tactical portrayal and use of narrative elements to expand, contain or otherwise manipulate the involvement in the policy arena' (Shanahan et al., 2013: 458).

The full range of narrative elements and strategies identified in the literature are too numerous to cover here in full, but include those borrowing from rhetorical, semiotic and literary analysis (Feldman et al., 2004; Riessman, 2008). In several accounts, different elements and strategies are employed depending on whether the narrative is narrated or received by an individual or a group (Jones and Mcbeth, 2010; Riessman, 2008). Useful recent guides include Reissman (2008), who divides narrative analysis in the human sciences into thematic, structural, dialogic/performative and visual approaches, and a number of articles by the authors of the Narrative Policy Framework ${ }^{2}$ (NPF) (Jones and Mcbeth, 2010; Mcbeth et al., 2007; Shanahan et al., 2013). This latter body of work is particularly useful in identifying specific elements and strategies commonly employed in policy narrative. Table 1 summarizes some of these key elements which may be relevant to a policy context operating at micro level and macro levels. A further explanation and demonstration of these approaches is provided in the analysis of the Indian case which follows.

\footnotetext{
${ }^{2}$ This latter body of work is commendable for the willingness of the authors to borrow from interpretivist and social-constructivist theory and analysis. They write: 'the politics of constructing policy reality appeared to be underspecified or missing from mainstream policy process theories' (Shanahan et al., 2013: 455). 'In short, NPF takes a systematic, scientific approach to understanding the social construction of policy realities' (ibid.).
} 
Table 1. Narrative Elements and Strategies

\begin{tabular}{|c|c|}
\hline Narrative elements & Description \\
\hline Plot/temporal elements & A beginning/middle/end or a historical account \\
\hline Characters & $\begin{array}{l}\text { Central protagonists of story usually framed } \\
\text { implicitly or explicitly as heroes, villains or } \\
\text { victims; or wider categories of winners and losers } \\
\text { (see expansion/containment) }\end{array}$ \\
\hline Moral & $\begin{array}{l}\text { The implied or explicit moral of a story; wider } \\
\text { lessons; policy prescriptions }\end{array}$ \\
\hline Causal Mechanism & $\begin{array}{l}\text { The logical connection of events, causes, effects in } \\
\text { the wider structure of the plot }\end{array}$ \\
\hline Narrative Strategies & Description \\
\hline \multicolumn{2}{|c|}{--Meso Level- } \\
\hline Expansion & $\begin{array}{l}\text { Narrative strategies which emphasize the } \\
\text { concentration of benefits and diffusion of costs (so } \\
\text { as to expand support/coalitions and external } \\
\text { involvement) }\end{array}$ \\
\hline Containment & $\begin{array}{l}\text { Narrative strategies which emphasize the wide } \\
\text { diffusion of benefits of a policy outcome and the } \\
\text { concentration of costs (so as to contain external } \\
\text { action and maintain status quo) }\end{array}$ \\
\hline Devil Shift & $\begin{array}{l}\text { Exaggerates the (nefarious) power of opponents } \\
\text { and understates that of the narrator(s) }\end{array}$ \\
\hline Angel Shift & $\begin{array}{l}\text { Exaggerates the benign power of the narrator(s) } \\
\text { and understates that of the opponents }\end{array}$ \\
\hline \multicolumn{2}{|c|}{--Micro Level-- } \\
\hline
\end{tabular}




\begin{tabular}{|l|l|}
\hline Canonicity and breach & $\begin{array}{l}\text { The extent to which a narrative persuades by its } \\
\text { presentation of a significant alternative to the } \\
\text { status quo (breach); or accords with it (canonicity) }\end{array}$ \\
\hline Narrative transportation & $\begin{array}{l}\text { The skill of the narrator/narrative in transporting } \\
\text { the listener into the narrative }\end{array}$ \\
\hline Congruence and incongruence & $\begin{array}{l}\text { The extent to which the narrative resonates with } \\
\text { accepted thinking on an issue }\end{array}$ \\
\hline Narrator Trust & $\begin{array}{l}\text { The devices and skills the narrator uses to } \\
\text { establish that their version of events is believable }\end{array}$ \\
\hline
\end{tabular}

Source: Adapted from Shanahan et al. (2013); Jones and McBeth (2010).

\section{METHODOLOGY}

The article focuses on a specific period of Indian public discourse described below which seems to have been at its most prominent from 2011 onwards and which peaked in 2013. Both Indian and global English language media were searched for references to the nutrition measurement of nutritional status and economic growth using an online search engine (Google) and a news media database (Lexis), with further searches carried out of specific media websites where possible, or databases allowing access to 'paywalled' publications such as the Financial Times. A further internet search via Google yielded further grey literature and blogs. Academic sources were also consulted. In total 40 sources were logged and analysed in a simple excel database, which the author used to code sections of the sources according to the narrative elements described in Table 1. This coding then becomes the basis of the analysis below, which follows a description of the wider context. The types of sources consulted are summarized in Table 2.

The limitations of this approach are in the decision to limit the search to the English language media and to focus the analysis primarily on media reportage, which does not do justice either to the richness of public and policy debates which occur unreported or those that are reported or are influential within India's vernacular media. Further work on these angles would certainly increase the utility of the analysis here. However, debates in the English language media in India - especially when provided with further fuel or impetus by the international media - are important both in terms of their influence on elite political 
debate and in their consumption by an English-speaking middle class which follows these debates. As such, these debates can be considered as an important form of policy narrative and worthy of analysis in their own right.

Sources are made explicit to give the reader a sense of the contexts within which the narratives were being performed - with an assumption that the readership of the Hindu or Outlook (centre-left to left) will be different to that of the Indian title Business Standard or to the London-based/global Financial Times. The search and analysis include pieces written directly by the main protagonists espousing competing narratives, pieces in which they are directly quoted, or pieces in which others (journalists or academics) are commenting on the same debate. The source of the narrative is also therefore made clear in the analysis where the main players are not being cited directly. The search was comprehensive but the analysis below has cited selectively for qualitative saturation rather than a catalogue of every media reference to the topic. Qualitative saturation (Guest et al., 2006; O'Reilly and Parker, 2012) was understood to have been reached when searches for additional sources brought no new significant angles to the narrative or departures from the thematic summaries contained below.

Table 2. Summary of Sources Consulted

\begin{tabular}{|c|c|c|c|c|c|c|c|}
\hline Type of Source & Pre- & 2010 & 2011 & 2012 & 2013 & 2014 & Total \\
& 2010 & & & & & & \\
\hline Newspaper or news magazine article (IN) & - & - & 2 & 3 & 4 & - & 9 \\
\hline Economic and Political Weekly (IN) & 1 & 3 & - & - & 8 & - & 12 \\
\hline Newspaper or news magazine article (GL) & - & 1 & 2 & 2 & 13 & 1 & 19 \\
\hline Blog & - & - & 1 & - & 1 & - & 2 \\
\hline Academic book or paper & - & - & - & 1 & 1 & - & 2 \\
\hline Press releases & 1 & - & - & - & 1 & - & 2 \\
\hline TV news & - & - & - & - & 1 & - & 1 \\
\hline TOTAL & 2 & 4 & 5 & 6 & 29 & 1 & 47 \\
\hline
\end{tabular}




\section{NATIONAL NARRATIVES OF NUTRITION IN INDIA - A HUNGAMA}

\section{Background to Stunting in India}

India's high levels of stunted children, that is, children significantly shorter than the globally recognized average (median) height for their age, ${ }^{3}$ has been acknowledged as a blot on the history of India's development trajectory by none other than the former Prime Minister (2004-14) Manmohan Singh, while in office. Stunting is a marker of more profound inadequacies in nutrition which impact both on cognitive and physical or physiological development - and so has lifelong consequences for both individuals and their families and for national development (Black et al., 2013). Singh noted India's high rates firstly in an Independence Day Speech in 2007, reflecting on recently released data showing India's rate of child stunting to be close to 50 per cent, but the subject made little further public waves for another few years, until it began to resurface in policy and media discourse (Government of India, 2007). In an address in January 2012 accompanying the launch of the Naandi Foundation's report 'Hunger and Malnutrition' (HUNGaMA) (Naandi Foundation 2011), which reported on survey results from selected districts across nine states in India, Singh declared: 'I have said earlier on a number of occasions and I repeat that the problem of malnutrition is a matter of national shame. Despite impressive growth in our GDP, the level of under-nutrition in the country is unacceptably high. We have also not succeeded in reducing this rate fast enough' (Government of India 2012) .

Hungama in Hindi can be translated as 'ruckus' and the publication of the report had been intended by its backers - the Citizen's Alliance against Malnutrition and the Naandi Foundation (who were supported by the company Mahindra and Mahindra) to raise such a ruckus on a somewhat neglected topic. National surveys on child height and weight required to produce statistics of stunting and wasting (the latter children significantly lighter than the median for their height) have occurred with decreasing frequency in India. There was a tenyear gap between the last full nationwide survey, the National Family Health Survey, as the NFHS-3 round (2005/6) and the NFHS-4 round (2015/6), and at the time of writing the full data from NFHS-4 have yet to be released. This lack of data has been a cause of dissatisfaction for nutrition advocates in India. The HUNGaMA survey (Naandi Foundation

\footnotetext{
${ }^{3}$ The WHO (2014) defines stunting as 'a height that is more than two standard deviations below the World Health Organization (WHO) child growth standards median'. Notably, it is this reference to the WHO standards that is in contention in one of the set of the narratives examined here.
} 
2011) was an attempt to fill this gap by focusing on what had happened in the interim across the 100 districts experiencing the worst deprivation across India. The figures, whilst not nationally representative, showed some improvement from the rates quoted by Singh, but were still high overall.

Data on nutrition have since been collected via a further 'Rapid Survey on Children' (RSOC) - carried out by UNICEF (Government of India and UNICEF 2016) on behalf of the government in 2013-14 (another dataset gathered in 2011-12 was the India Human Development Survey 2, but data were not available at the time of the debates documented here). According to the RSOC survey, India's headline rate of stunted children had declined from 48 per cent to 39 per cent - with an annual average rate of decline at 2.6 per cent representing a doubling of the rate of decline of previous years (IFPRI, 2015). Levels in some states, however, remain stubbornly high (including Uttar Pradesh at 50 per cent and Bihar at 49 per cent - see Fig. 1) and have reduced at a much slower rate. Notably, national prevalence is still at levels comparable to some countries in sub-Saharan Africa including, for example, Chad (38.7 per cent in 2010) or Tanzania (34.8 per cent in 2011), but lower than Ethiopia (44.2 per cent in 2011) or Sierra Leone (44.9 per cent in 2010) (ibid.). Such international comparisons were at the core of objections to the use of stunting data to compare India's progress on growth and poverty which form the heart of the narratives considered below. This was particularly so, when, lacking the updated 2013-14 data, India's earlier headline rate of 48 per cent pitched it at among the worst in the world. 
Fig 1. Rates of Stunting in 29 Indian States - 2005/06 and 2013/14.

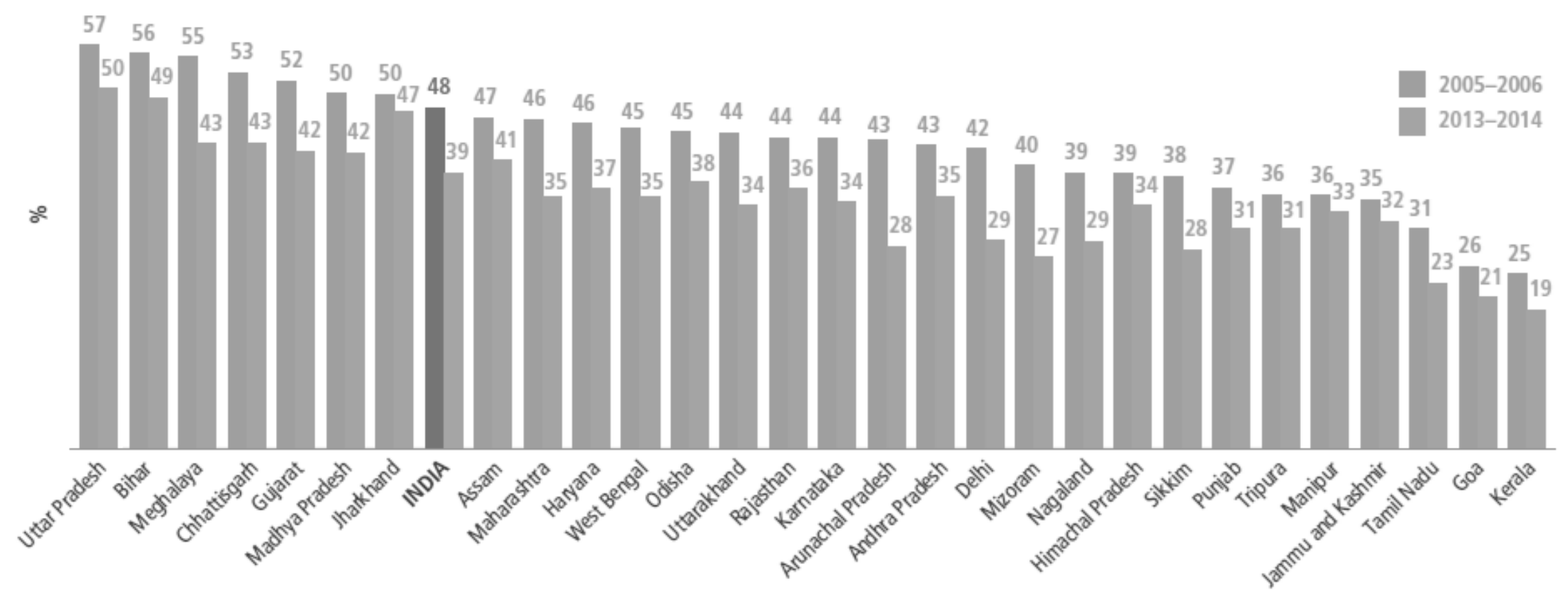

Source: IFPRI (2015). 


\section{Competing 'Myths' of Malnutrition: Panagariya and Bhagwati versus Dreze and Sen.}

The Naandi Foundation's report succeeded in its aim of creating a hungama and focusing high-level political and media attention on the issue of undernutrition. But nutrition had already been a focus in the media in the preceding months and years to the release of the report, with some powerful players espousing very different narrative interpretations, not just of the figures, but their very validity in the Indian context.

An opinion piece in the Times of India published on 1 October 2011 by the University of Colombia trade economist Arvind Panagariya sought to explode the 'myth' of child malnutrition - that is, the absurdly high estimates of malnutrition in India trumpeted by journalists, NGOs, politicians and international institutions within and outside India (Panagariya, 2011). According to Panagariya, 'Not a day goes by without some TV channel or news running the headline that the world's fastest growing economy suffers worse malnutrition than sub-Saharan Africa' (ibid.). Panagariya drew attention to the logical inconsistency in the fact that India's stunting and underweight figures are higher when compared with sub-Saharan African (SSA) countries, even though infant and maternal mortality rates are generally much higher in the latter region. This had prompted him, he wrote, to look further at how stunting and underweight are calculated according to the globally accepted methodology set out by the WHO growth standards, which compare children to the normal distribution of children's heights and weights set according to a population of children sampled from six countries across the world. In the WHO standards, only children greater than two standard deviations below the median height - that is, 2.14 per cent - of the population are classified as stunted. India's rate is significantly higher (48 per cent in 2006-07), and is high, he wrote, even when considering only a wealthy subsample, drawn from the 2005-06 data. This could only mean that the standards themselves are inapplicable to India - a fact which makes sense of the discrepancy between Indian and SSA performance if it is considered that SSA countries have a genetic advantage in terms of height:

The implication of this and other facts is that Indian children are genetically smaller on average. A competing hypothesis which says that nutrition improvements may take several generations fails to explain how, without a genetic advantage, the far poorer SSA countries, which lag behind India in almost all vital statistics, could have pulled so far ahead of India in child nutrition. (Panagariya, 2011) 
Countering this argument, a longer piece soon appeared as a cover story in the weekly national news magazine Outlook, written by the eminent economists Jean Dreze and Amartya Sen, entitled 'Putting Growth in its Place' (Sen and Dreze, 2011). This further developed an argument which had already raised some public controversy in 2010, when the Financial Times reported a speech by Sen to young entrepreneurs in Delhi (Lamont, 2010), chiding an obsession with surpassing China's rate of economic growth in the face of poor human development indicators, in particular nutrition.

In the Outlook piece, Dreze and Sen depart from the same starting point as Panagariya in outlining the discrepancies between India's rates of growth and its health and social indicators. The piece starts off by stating and comparing two 'stories' which attempt to answer the question 'Is India doing marvellously well, or is it failing terribly?' (Sen and Dreze, 2011). One story, they argue, can be characterized as stating that the Indian economy has taken off since liberalization, thanks to the opening of the market. Inequality has increased, but this is normal and 'with enough time, the benefits of fast economic growth will surely reach even the poorest people, and we are firmly on the way to that' (ibid.). The other story, they argue, can be characterized as stating the 'progress of living standards for common people, as opposed to a favoured minority, has been dreadfully slow — so slow that India's social indicators are still abysmal', particularly when comparing indicators such as youth female literacy, child mortality, sanitation or child underweight. The article then goes on to expand on the argument first advanced in their book Hunger and Public Action (Dreze and Sen, 1989) that whilst growth is important, it requires both redistribution and fast investment in basic services, particularly health and education.

Much of the rest of Dreze and Sen's article is then concerned with comparing India with neighbouring South Asian countries and China and explaining why political choices lead to particular social and health outcomes - pointing to Indian states such as Tamil Nadu and Himachal Pradesh, which they say had been more successful in turning economic growth into pro-poor growth through well-run universal, social and health programmes.

The Times and Outlook articles were a rehearsal for a debate that continued over much of the course of the next two years in the English language media. Panagariya repeated these claims in a Business Standard interview in July 2012 (Sharma, 2012). Here he named Jean Dreze and expressed his puzzlement that Dreze seemed to have earlier supported the potential genetics argument but makes no mention of it in the Outlook piece. In September, Panagariya presented a full version of an article at a workshop at Columbia University in which he took issue with a piece in the Economist noting the national shame of India's 
undernutrition figures (Panagariya, 2012). Here he expands on the argument in the Times opinion piece and brings in a wider range of evidence to look particularly at linear growth in different cultural contexts, restating his conclusion that either Indian height is genetically predetermined to be shorter than the global average and/or that the idea that catch-up growth may take several generations is based on fallible evidence.

The debate was to flare up at various times as both the Indian English language and international media continued to pick up on the claims and counter claims and, increasingly, some of the open hostility between the key proponents on either side. It became clear that the earlier pieces had been previews of some of the central arguments of two books to be published in 2013. Why Growth Matters: How Economic Growth in India Reduced Poverty and the Lessons for Other Developing Countries by Bhagwati and Panagariya (2013) was published in March and An Uncertain Glory: India and its Contradictions by Dreze and Sen (2013) was published in June. Accompanying publicity, interviews and book reviews (explaining the peak in Table B) meant that the public clash of narratives continued in the Indian press and prominent international outlets. These included the Economist, Wall Street Journal, New York Review of Books and the Lancet - with commentaries from the likes of people such as the writer Pankaj Mishra (Mishra, 2013) and the eminent economist Angus Deaton (Deaton, 2013). Notably, Panagariya was asked to present a version of his article as the Chandrasekaran Memorial Lecture at the Indian Institute of Population Studies, Mumbai, ${ }^{4}$ in November 2012.

The narratives on nutrition develop and vary in different retellings by the central narrators and by others. Notably, whilst central, these narratives are only one of several related arguments set forth by the protagonists in the media or their respective books and articles. The concern of this article is a narrative linking growth and malnutrition that is continuously retold in the sources examined, and, in the tradition of narrative policy analysis, a concern with what it stands for and tries to achieve. Both sides of the narrative are renarrated by several others in the media in reference to the central protagonists - including other prominent individuals who re-narrate and comment on its implications. Whilst this makes it hard to do justice to and characterize the narratives accurately, what follows is an attempt to retell the narratives in a manner that incorporates most of the key elements.

\footnotetext{
${ }^{4}$ The organization charged with running India's National Family Health Survey, which measures child height and weight.
} 
The Inclusive Growth Narrative (Dreze and Sen)

Triumphalism about India's growth is unfounded. India has grown, and growth is important for poverty reduction. But if measured not in GDP but in health and social indicators, other countries have been much more successful at improving the lives of their populations. Nowhere is this clearer than in the prevalence of child undernutrition. India compares unfavourably to African countries, South Asian neighbours and BRICs. This should be a source of shame to an elite obsessed with economic growth. India, rather than being triumphant, needs to follow trajectories of others in terms of public investment. Eventually this will pay off in broader-based growth.

The Two-track Growth Narrative (Bhagwati and Panagariya)

Liberalization has led to tremendous economic growth in India and that growth has led in turn to poverty reduction. Health and social indicators are good. The authors were puzzled by undernutrition figures until they examined them in more detail. The figures are based on WHO standards which do not apply to India. When India-specific standards are considered, undernutrition rates are in keeping with its (positive) improvements in health. Some public figures have used undernutrition rates to object to or attempt to slow the progress of liberalization. Not only are these figures now proved as wrong, but global evidence shows that social/health improvements rely first on liberalization reforms aimed at increasing growth (track 1 reforms) which in turn fund investments and improvements in health and education (track 2). A focus on large social programmes is a fiscal risk to fragile growth, threatening to slow reform; and a misplaced focus on undernutrition in India will simply lead to overweight children.

\section{WHY THESE NARARTIVES AND WHY A NARRATIVE POLICY ANALYSIS?}

At this point it is worth pausing to consider why one might consider these competing arguments as policy narratives worthy of further analysis in their own right. To be deemed as such, we must consider them both as narratives (i.e. exhibiting the characteristics and elements or strategies explained above), and as having a strong policy intent (Shanahan et al., 
2013: 457). Furthermore, whilst not selected as representative - it needs to be explained how the narratives on both sides are reasonably emblematic of arguments put forward by wider ideological positions. In this case, these are positions advocating for greater or lesser investment in basic health and education as, alternatively, the precursor to - or the dividend of - wider economic growth.

For a start, both sides advance their own arguments by explicitly discussing myth and narrative (Panagariya), and competing stories (Dreze and Sen). The themes of myth, narrative and stories recur both through their own media discussions and the commentary of others. It is clear from the material already presented that both sides see shaping a narrative on nutrition (and other social indicators) as an argument about India's economic growth. In both cases, they present countervailing meta-narratives of their own which cannibalize these myths and stories, either through considering the internal inconsistencies in one narrative (Panagariya) or via the resolution of oppositions prescribed between the two competing narratives (Dreze and Sen).

Both sides are influential. All four are among the most prominent of Indian economists, and all have connections to leading politicians of the left on the one side, and the right on the other. Dreze was close to the centre of power in his connection to the national ruling coalition of 2004-14, the United Progressive Alliance - a left-leaning coalition ruled by the Indian Congress Party which was supportive of the large central social schemes of which Dreze was one of the greatest advocates. His links to power included a reported closeness to Sonia Gandhi (the Chair of the Indian Congress Party) and his earlier role on the National Advisory Council, ${ }^{5}$ the creation of the National Employment Guarantee Act (Chopra, 2011a, 2011b; Khera, 2011) and his influence within the campaign advocating ultimately successfully — for a National Food Security Act, which Sen also strongly supported. Bhagwati was a contemporary of Manmohan Singh at Cambridge. An influential trade economist, he was a strong proponent of trade liberalization and an advocate of the Washington Consensus. He held positions advising the WTO, GATT and the UN as well as, earlier, the Indian Planning Commission. Panagariya holds the Bhagwati Chair in Economics

\footnotetext{
${ }^{5}$ An advisory body set up by the ruling Congress party chair, Sonia Gandhi, to provide advice to the coalition governments in 2004-09 and 2009-14. The body included several prominent activists and scholars and was criticized for being an alternative source of power to the government and its formal bodies, including the National Planning Commission. It was influential in proposing and advocating for several important pieces of legislation, including the National Rural Employment Guarantee Act - a work based social protection scheme introduced across India. For more detail on the political economy of the NAC and its interaction with other domains of government and civil society see Chopra (2011a, 2011b).
} 
at Columbia and was Chief Economist at the Asian Development Bank. He was eventually to come out as a strong supporter of Narendra Modi as a prime ministerial candidate and the pro-business and liberal 'Gujarat model' of growth. In January 2015, after Modi came to power, Panagariya was awarded the influential position of Vice Chairman of the new Indian Policy Commission (replacing the Planning Commission), the NITI Aayog.

Studying these claims as examples of narrative is not to suggest that they are the only prominent narratives on this subject. Such narratives play a part within a wider discursive field where narratives on growth, poverty and food insecurity abound. In other related and important technical debates protagonists can be found debating the relationship between grain and calorie consumption and measurement of poverty - which again are seen as measures critical in determining the success or otherwise of India's orientation towards growth postliberalization. ${ }^{6}$ This set of narratives have been selected given the central roles of the narrators both in the ways in which the narrative has played out in public view in the media, but also in their proximity to policy.

It should not be assumed that narrative analysis is the only way analysts can and should engage with the debate. Panagariya's article questioning the 'myth' of Indian nutrition was pitched as a more technical piece and was eventually to become an article in the prominent and influential weekly journal Economic and Political Weekly in May 2013. This was followed by a series of point-by-point rebuttals made by prominent nutritionists, paediatricians and economists (including Dreze) in August that year. This article does not attempt to contribute further to the debate on this technical level. However, given that these responses were part of and informed the wider set of narratives concerned with this subject within the Indian context, a precis of the responses to arguments put forward by Panagariya is presented in Box A.

\footnotetext{
${ }^{6}$ See Deaton and Drèze $(2009,2010)$ and Patnaik $(2010 a, 2010 b)$.
} 
Box A. Technical Responses to Panagariya in EPW

\section{Summary of Key points}

In responding to Panagariya's arguments about growth measurement and genetics, authors in the special issue of Economic and Political Weekly drew attention to the points below. There was no further rejoinder by Panagariya.

- There was no significant statistical difference found between the growth of Indian children and other children (Norway, US, Brazil, Ghana and Oman) in an 8,440 strong cohort in the WHO 'Multi-Growth Reference Study' used to set the WHO standards. This means that no assumption can be made of any genetic difference on the basis for the attainment of child height amongst Indian children (Lodha et al., 2013; Wable, 2013; Gillespie, 2013).

- Panagariya has missed the point of the normative role of the WHO standards in his argument about a privileged section of Delhi children in the sample (Lodha et al., 2013). The fact that children were included from an optimal level of family income and education and were breastfed (Gupta et al., 2013) was deliberate and intended to show what children could achieve in optimal conditions, becoming the normative standard against which child growth should then be measured. Wider evidence on the genetics of the Indian population does not support the argument for any Indian genetic specificity when compared to European or African genetic makeup (Lodha et al., 2013).

- Panagariya confounds the evidence and debates on factors leading to variation within adult heights and child heights (Wable, 2013) and himself cites evidence which questions the logic of any Indian genetic difference (including that Indian average heights are on the rise and that Indian children grow taller when raised in less-poor environments). These point to environmental factors overcoming any such genetic lag (Wable, 2013).

- The genetic explanation for the variations in height which do exist in the Indian population has to be more than a residual explanation after other explanations are ruled out (Coffey et al., 2013). But Panagariya fails to examine key explanations of Indian variation existing for a long time in the academic literature (Gillespie, 2013; Coffey et al., 2013; Lodha et al., 2013). These extend beyond food to include the unsatisfactory disease environment (constant illness can be an explanation of poor growth just as much as lack of food); the position of women and slower comparative progress in women's empowerment (Coffey et al., 2013); alongside wider structural deficiencies inherent in poverty and poor investment in social programmes (Gupta et al., 2013) . He also fails to examine newer and persuasive evidence on the links between India's high levels of open defecation and gut disease 
(Gillespie, 2013; Coffey et al., 2013) and differences in intra-household allocation and birth spacing (Jayachandran and Pande, 2013).

\section{NARRATIVE ELEMENTS}

Rather than engaging further on this technical level, the purpose of this article is to consider what can be added by a consideration of what narratives can and do set out to achieve in a policy environment. Having decided on the validity of considering these as competing narratives, this section further considers their narrative composition in utilizing some of the analytical tools discussed earlier. These include identifying those standard elements noted in most analytical accounts of narratives, such as characters, plot and temporality. This is followed by a reflection on the way in which narratives attempt at persuasion through a number of techniques familiar to narrative policy analysis. These include wider mesostrategic elements (winner/loser portrayal) and the use of rhetorical devices, such as canonicity and breach, narrative transportation and congruence and incongruence to establish narrator trust (see Table 1).

\section{Characters, Heroes and Villains}

If there is a consistent set of elements that nearly all analysts of narrative agree on, it is the need for characters, plot and a moral (Dodge et al., 2005; Jones and Mcbeth, 2010; Shanahan et al., 2013). Understanding the narrator's choice in the selection of characters, the portrayal of those characters (particularly as heroes or villains) and the events that they create or experience, and noting the physical settings in which these events occur, are the basics of narrative analysis (see Table 1).

In the narratives examined here, the primary characters are twofold — they include both a range of characters designed to illustrate the argument, and they include the central narrators or protagonists themselves. The first set of primary characters are categories of people expected to be affected positively or negatively by reform. They are generally quite broad categories (in keeping with the rhetorical device of expansion discussed below), 
including 'the poor' or 'BPL families', ${ }^{7}$ malnourished children, underweight or anaemic mothers, lower caste and class groups. A key and broad category, often implied more than made explicit, is the Indian public in general.

Other general characters then stand as illustrative characters in the debate - mainly by way of comparison (children or women in Africa); passing comment on one version of the narrative or another (business people, Indian and global economists, nutrition experts, politicians); or chastised for their inaction (elected members of parliament, civil servants).

Alongside people as characters, it is clear that both narratives are also about the story of nations - in fact, to stretch this further, it could be argued that countries themselves are key characters. These extend beyond India to its wider neighbours in South Asia, to South East Asia, Japan, China and the other emerging economies, and to countries in sub-Saharan Africa. The choice of countries is important as they play a role in comparing and contrasting with India's own historical narrative and eventual destiny, and thus form a central part of the plot, temporality and moral to which we turn in the next section.

In keeping with other policy narratives, a number of the characters take on more normative roles as heroes or villains. Neither side seems to have much good to say about a group classified alternatively as 'New Delhi's policy Elite', 'the Indian Elite', or 'the New Delhi establishment'. They are portrayed as either wilfully ignorant of India's staggering inequalities, or as a bureaucratic or leftish blockage on further growth (Panagariya, 2011). External villains in Panagariya's narrative on the measurement of malnutrition include the World Health Organization, which 'ha[s] criticised India's high rates of malnutrition'. Both the $\mathrm{WHO}$ and the UN are characterized as representative of a 'huge lobby of very powerful international organizations, academics, NGOs and journalists' behind the MDGs (Panagariya in Jain, 2012), and, by implication, conspiratorially willing to bend the international indicators they set to their own advantage (i.e. towards increased development spending which will only feather the nests of these actors).

Heroes are harder to find in both narratives. However, implicitly (and occasionally explicitly) they can be said to be the central narrators themselves, playing a role in upsetting established truths and providing an alternative narrative and set of policy implications in their commentary on the policy issue. Mostly, however, the narrators do not explicitly insert themselves into the narrative, but they frequently insert each other. Other commentators in the media debate also enlarge the narrators' roles as central characters by filling in their

\footnotetext{
${ }^{7}$ Families classified as living at a level below India's poverty line.
} 
backgrounds. Sen's Nobel Prize is frequently referred to, Panagariya is characterized as a 'myth buster par excellence, contrarian and reformist' (Sharma, 2012), and Bhagwati a longterm champion of reforms, whilst Dreze is rated highly as an economist, but also as a social activist. Often the external commentators draw readers' attention to the personal rivalry that marks this debate (see, for example, Rajadhyaksha, 2013), but by the summer of 2013, this becomes unnecessary, as the debate spills over into explicit arguments with each other - in the letters pages of the Economist and in prominent Indian newspapers, websites and on television. Bhagwati and Panagariya wrote to the Economist to express their displeasure at a favourable review of the book by Dreze and Sen. Here, they attack Sen, who they wrote 'belatedly learned to give lip service to growth, which he has long excoriated as a fetish' (Bhagwati and Panagariya, 2013). Sen wrote back to defend his record and clarify his argument, writing that 'Economic growth is very important as a means for bettering people's lives, but "to go much further, faster" (as your reviewer commented) it has to be combined with devoting resources to remove illiteracy, ill health, undernutrition and other deprivations' (Sen, 2013a).

An article that appeared in the online business newspaper Mint in July of that year clarified another dimension to the debate. In arguing that 'Gandhi vs Modi is actually Sen versus Bhagwati', it highlights the aforementioned way in which key protagonists were standing as proxies for the political actors who would go on to contest the 2014 national elections (Rajadhyaksha, 2013). Additional media contributions further drew these direct links to politics. Later that month in an article in Mint, Bhagwati reasserted his contention that Sen has the rare accolade of having twice inflicted damage both on policy and the poor/poverty reduction - first by opposing the 1991 reforms and second by supporting populist measures, including the National Food Security Bill (NFSB) (Bhagwati, 2013b). In the article, Bhagwati refers to an earlier television debate in which Panagariya unexpectedly turned up to debate with Sen on the National Food Security Bill. That debate, according to Bhagwati, then degenerated into farce: 'On the same programme, Sen's friend, the activist Jean Drèze, produced some toy animals and told Panagariya that he was a unicorn! He is lucky that Panagariya did not respond bitingly and say that Drèze should have described 
himself as the Nandi bull, with his senior colleague Sen as Lord Shiva ${ }^{8}$ who had hurt masses of India's poor' (ibid.).

In a later television appearance Sen pointedly refused to endorse the 'Gujarat model' or a Modi candidacy for the national leadership, citing the Chief Minister's inability to protect the Muslim minority from the 2002 riots in Gujarat and that state's poor record on education and healthcare (Sen in CNN-IIBN, 2013). An ever more public furore resulted, with an MP of Modi's party, the Bharat Janata Party (BJP) (who were then in opposition), calling for Sen to be stripped of his Bharat Ratna - the country's highest civilian award (CNN-IIBN, 2013). The whole debate was then picked up internationally, with a useful summary of events given in a blog in the Wall Street Journal in late July (Acharya, 2013).

This self-reference, or reference to one's opponents, perhaps should not come as a surprise given the prominence of the main protagonists and their potential influence over the debate. This move - ascribing particularly nefarious motives to the opposition is a classic move in such narrative policy debates classified as a 'devil shift'. The accompanying selfreference of the protagonists in their roles helping right the wrongs of public policy (or the earlier focus on growth and social reforms, etc.) can similarly be classified as an 'angel shift' (Shanahan et al., 2013).

\section{Plot, Moral and Causal Mechanisms}

The various narratives differ significantly in their treatment of nutrition and the policy choices that might arise from this treatment. They cover a lot of similar historical ground, albeit with different interpretations in terms of outlining past causal mechanisms which link policy choices to welfare outcomes. They act, therefore, as a moral tale of India's past, recent and future economic growth. In Sen's version this stretches back to the colonial period, noting (in implicit reference to his famous work on famine) how 'the Raj began with a famine and ended with a famine' (Derbyshire, 2013). However, both he and Dreze also make frequent reference to the country's successful transition to a sovereign, multiparty democracy. Both sides seem to accept that the economy has grown significantly in the last

\footnotetext{
${ }^{8}$ Nandi is the Sanskrit name for the head attendant and companion of the Hindu god Shiva who was given the form of a bull and among other roles worked as a gatekeeper to Shiva. Shiva has many forms and depictions, among which is a reputation for ruthless destruction.
} 
two decades. The two camps also accept to varying degrees that this was as the result of the reforms undertaken by Manmohan Singh, when Finance Minister, in response to the foreign exchange crisis of 1991. The two narratives can also be characterized somewhat similarly in encompassing wider fears of decline (another common theme in the narrative policy literature, Stone, 2002). Sen, for example, notes that the recent decline in India's rates of economic growth means that any hopes of India overtaking China have been dashed (Sen, 2013b), whilst Panagariya and Bhagawati also flag stagnant growth since the Congress-led coalition came to power in 2004 (Rajadhyaksha, 2013; Sharma, 2012).

Another current historical backdrop that forms a key element of the plot is the aforementioned and frequent comparison of India's growth and development trajectory with that of other countries. Alternatively, it is these other countries' investment in human capital, or more successful pursuit of reforms, which are compared. Comparison with the rest of South Asia is useful as, having a shared colonial history and a more or less similar (poor) starting point in terms of social and health indicators, it can be seen as a sort of historical natural experiment in the impact of different growth trajectories on social and health indicators. ${ }^{9}$ The wider trajectory of countries in South East Asia, sub-Saharan Africa and the other emerging economies of the BRICs are also seen as a useful counterpoint by both sides when wanting to make a point about growth, public investment and India's assumed place in the world.

A further two sub-plots are also visible within the narrative. One is of the central protagonists' own journeys of discovery. Bhagwati, for example, characterizes his own journey from Planning Commission poverty specialist to Washington Consensus advocate (or architect), whilst characterizing Sen's journey as having shifted his position from a disavowal of the importance of growth 'to his recent discovery of growth' (Bhagwati and Panagariya, 2013). Dreze and Sen, on the other hand, detail how their own interest in determining whether India's growth story really did benefit the wider population was triggered in part by the malnutrition figures and other 'dismal' social indicators (Sen and Dreze, 2011).

The other sub-plot describes the embodied story of the sufferers of undernutrition, which relates to the intergenerational nature of the condition itself. It describes how undernourished children are born to undernourished mothers, who can grow up to be undernourished mothers in turn. Given that intergenerationality makes 'catch-up growth' a

\footnotetext{
${ }^{9}$ For a technical version of this see, for example, the comparison of malnutrition across the Bengali India/Bangladeshi border by Ghosh et al. (2014).
} 
difficult prospect, it is something Panagariya discusses at length as the ability for catch-up growth would undermine his central argument for the genetic nature of Indian short stature ${ }^{10}$ (Livemint, 2013; Panagariya, 2012).

\section{Rhetorical Devices and Strategies}

The key proponents are known to be 'gifted polemicists' (Rajadhyaksha, 2013) which is apparent when examining the various rhetorical devices employed in their narratives. One of the most common strategies is to portray particular figures, facts or the opposing argument in general as out of keeping with accepted thinking, exaggerated, outside of or failing in scientific standards. Examples of this are legion - Panagariya refers to the 'absurdly high estimates of child malnutrition' (Panagariya, 2011) whilst Sen refers to '[t]he Indian fixation with surpassing China's rate of economic growth [as] "very stupid"' (Sen cited in Lamont, 2010).

In Panagariya's case, this is part of a wider rhetorical strategy of signalling congruence and incongruence (see Table 1) (Jones and Mcbeth, 2010), which asks the listener to judge whether a narrative resonates because of its consistency with accepted beliefs. So the constant comparison to sub-Sahara Africa, which many of the Indian elite might perceive as rather backward in relation to India, is designed to ask the listener to consider whether the malnutrition figures could possibly be true. Conversely, the assertion is that if one overturns the methodology behind the measurement of child malnutrition, India's place within the world is reasserted, ${ }^{11}$ as is the wider congruence with a neoliberal narrative of growth unfettered by state and social spending.

The use of the 'devil turn', in which narrators exaggerate the malice of their opponents has been noted earlier and is a key rhetorical device (Shanahan et al., 2013). It creates conflict and adds motivations and insinuations - for example, in the case of the WHO/UN and others who 'bulldozed' (pushed through) the use of international standards that so shamed India (Panagariya cited in Jain, 2012). Use of the devil turn often takes place alongside personal attacks on opponents and attempts to draw attention to the incongruence

\footnotetext{
${ }^{10}$ This is discussed in more detail in the technical responses to the debate in the EPW special issue.

${ }^{11}$ That is: superior to Africa, with Indian bodies and minds considered superior to those of Africans, progressing further than its neighbours and along the track of the other BRICs.
} 
of their claims by portraying them to be so absurd as to be dangerous. Thus, according to Bhagwati, Sen does 'serious damage' to the Indian economy (Bhagwati, 2013b).

Another rhetorical device which accompanies the signalling of congruence/incongruence is to try to build narrator trust via appeal to both reason and reasonableness. The latter takes the form of presenting the reader or listener with a sense of the need to consider compromise. This includes, for example, Dreze and Sen outlining two competing narratives at the beginning of their own narrative (triumphal growth versus failed liberalization) (Sen and Dreze, 2011), and their insistence that they are not anti-growth. This also includes Panagariya's appeal to his readers that 'I have an open mind, you've got to be able to change your mind' (Panagariya cited in Sharma, 2012) and his recognition that despite the fact that he goes to great lengths to dispute the malnutrition figure, malnutrition is still 'not an insignificant problem' (Panagariya, 2012). The appeal to reason is a very common strategy in policy narrative rhetoric, exhibited here as a constant appeal to scientific knowledge from both sides, whether in citing statistics and evidence to assert their own case, or to undermine the other's. Examples include those accusations of the other side's argument as having 'nothing at all by way of scientific justification', that it is exaggerated or based on 'shaky figures' (Sen, 2013b; Ullekh, 2013), or Sen's call for the need for systematic work (Sen cited in Derbyshire, 2013). As the presentation of scientific reason of both sides can seem both plausible and reasonable to the lay reader, this strategy may not itself be decisive — a common characteristic of such 'wicked' problems (Shanahan et al., 2013).

Finally, the narrative arguments of both sides can be considered to be utilizing the devices of issue expansion and containment (see Table 1). These are strategies that alternatively try to maximize the perceived winners of a problem and minimize losers when in favour of a particular position or the status quo, or that minimize winners and maximize losers when in opposition. In Sen and Dreze's narrative this is primarily a strategy of issue expansion, which highlights the categories of the poor, children, caste and class as substantial categories of losers, whilst winners are considered to be the 'policy elite' or growth fetishists - 'a minority but large enough group of Indians who are doing very well' (Sen and Dreze, 2011).

Panagariya and Bhagwati's strategy is also primarily one of issue expansion and can be witnessed in their efforts to point out the ways in which social spending (on issues such as nutrition) acts as a block on growth, leaving less money for other priorities. The Indian economy, population as a whole and wrongly diagnosed children (who in receipt of nutrition support risk becoming obese) are therefore a further significant set of losers in this device of 
expansion. The winners are variously the Congress-led coalition, the left, the anti-reformists, and the global agencies pushing the globally standardised malnutrition measures and figures.

However, some of Panagariya and Bhagwati's narrative can also be cast as a containment strategy in its defence of the overarching current focus on growth (even without the vigour they would like to see). Their argument here is essentially one of winner maximization within the current status quo as all will benefit eventually from wider growth that emerges from further reforms, enabling more investment down the line in areas such as health and education.

\section{CONCLUSION}

Through a review of relevant literature, this article argued that the purpose of good narrative (policy) analysis is to bring to the fore the intended meanings and implicit or tacit knowledge bound up in narrative, and to use this to deconstruct the wider norms or beliefs of which narrative can be emblematic. Increasingly in wider public life, political and policy narratives are being articulated and commissioned knowingly and explicitly as narratives, with the aim of extending regimes of knowledge and power. Attention to narrative strategies can therefore aid in understanding the intentionality of narrative as part of a wider discursive field and, in so doing, help manifest the power of the narrator.

This case has shown how a seemingly incontestable position (the measurement of child height and weight) can become a battleground of competing narratives on a country's development trajectory, past, present and future. A basic application of the Narrative Policy Framework approach ${ }^{12}$ as a useful synthesis of earlier - mostly interpretative - work on the topic, provides rich analysis. It has facilitated a consideration of both the common narrative elements (characters, plot, moral) and the strategies (e.g. containment, expansion, devil and angel shifts) that are incorporated into these particular narrations. The combined effect of these various elements and strategies is simply narratives which resonate better. This allows

\footnotetext{
${ }^{12}$ As developed by/Please see Jones and Mcbeth (2010); Mcbeth et al. (2007) and Shanahan et al. (2013).
} 
them to do important work in privileging and closing off various understandings of policy and political options; providing interpretations or re-interpretations of historical, political and economic trajectories; and extending public perceptions of new technical domains.

Bringing to light intended meanings and values here was not difficult given that the narrators make this an explicit commentary on India's growth trajectory. Whether tacit knowledge is required to interpret the narratives is determined partly by the audience's familiarity with the trope of characters as comparators. For example, the panic which greets any unfavourable comparison with sub-Saharan Africa indicators of health and human development or a sense that catching up with China is a distant prospect, requires a knowledge of the triumphalism of recent Indian growth discourse and perhaps some assumptions of an inherent Indian genetic superiority to Africans which lurk not far beneath the surface.

These narratives were chosen as particularly emblematic and powerful narratives of protagonists central to sources of both technical and political power. Other and wider narratives exist on each of the topics examined here (nutrition, food security, growth, sustainability, ${ }^{13}$ poverty, technical standards, etc.), at both national and global levels. This is no less the case than in the measurement of poverty and growth, where key technical issues of measurement become an important battle about the overall direction of growth itself. As Deaton has remarked on poverty, 'The India poverty data are controversial and not easily interpreted, and the literature contains claims that range from no acceleration in poverty reduction to there being little poverty left' (Deaton, 2013: 1015). Similarly, Deaton and others have questioned the headline growth figures due to the weakness of India's national growth accounts (ibid.: 1016). Whilst the task of narrative is to summarize and present such technical debates in a way that resonates with both lay policy makers and the general public, its danger to effective public discourse is that, without fuller knowledge of the technicalities and nuances, it can work to obscure as much as it clarifies. Nutrition (and the measurement of nutritional status) is one such subject which is both very technical and easily presented within a narrative of policy 'common sense', as part of the wider political/discursive strategies discussed here.

\footnotetext{
${ }^{13}$ With regard to wider debates on growth and sustainability, Partha Dasgupta has pointed out that there is not a great deal of difference in the two narratives examined here - theirs is mainly an argument about the proper sequencing human capital investment and pro-growth reforms - and in so doing, it ignores wider debates raging on, for example, the role of and degradation of natural capital in the growth story (Dasgupta, 2013).
} 
Interestingly, in the Indian context, the foregrounding of nutrition as a proxy for low human development originates from those broadly on the left of the political spectrum to broker a wider debate on the failure of neoliberal growth. Elsewhere, however, 'nutritionism' is increasingly being criticized by those on the left for being the handmaiden of such neoliberal growth. Such works point to the links of quick 'nutritional fixes' (Kimura, 2013) of micronutrient supplementation and wider drives in agricultural contexts to commercialize poor people's markets (Patel et al., 2015). Such cures and strategies are criticized as obscuring the need for wider structural and political reform to meet the needs and situations of poor people in terms of basic needs for food, effective health systems and employment (Kimura, 2013; Patel et al., 2015). However, such counter-remedies are not so very different from those prescribed by the likes of Dreze and Sen in the context of their own 'nutritionism' in India. Proclamations on the rise of the new 'nutritionism' therefore need to take into account how narratives of nutrition are playing out differently in these different discursive contexts, both in support of - and in opposition to - neoliberalism. It is hoped that this article can contribute to a fuller debate on this topic.

In contrast with some of the key Narrative Policy Framework literature, the approach taken here has not attempted to demonstrate the link between the strategies employed and whether or not a particular side perceives themselves or is perceived to be 'winning' a policy argument. To draw on this insight, it might be hypothesized that Panagariya and Bhagwati's often more vitriolic attacks on Dreze and Sen (and Sen in particular) were as a result of the latter's proximity to power. In this instance, this proximity is both 1) political, via direct links to policy formulation and prioritization in the Congress party-led coalition until 2014; and 2) technical, being part of the dominant consensus amongst most economists and scientists over the measurement and interpretation of children's heights and weights. One might further speculate then that given both concrete and indicative signs of change in both these domains, which include the ascension of the Modi government and the appointment of Panagariya as Deputy Chairman of the NITI Aayog, that strategies may yet change on both sides - but this remains to be seen. With further analysis over the longer period of the two administrations, one might also gain a better sense of how such a narrative/discursive regime both reflects overall changes in political regimes - and can be part of the wider process of political and popular dialogue which leads to such change. Both are indicative of the real links between narrative, the discursive and the material. 


\section{REFERENCES}

Acharya, N. (2013) 'The Friday Briefing: Battle of the Economists', The Wall Street Journal 26 July. http://blogs.wsj.com/indiarealtime/2013/07/26/the-friday-briefing-battle-ofthe-economists/

Berg, A. and J.I. Hukkinnen (2011) 'The Paradox of Growth Critique: Narrative Analysis of the Finnish Sustainable Consumption and Production Debate', Ecological Economics 72: $151-60$.

Bhagwati, J. \& A.Panagariya (2013) Why Growth Matters: How Economic Growth in India Reduced Poverty and the Lessons for Other Developing Countries. New York: Public Affairs.

Bhagwati, J. (2013b) 'Why Amartya Sen Is Wrong: Jagdish Bhagwati’, Mint 23 July. www.livemint.com/Opinion/9Qzg05zypjEUbioqK9N1UM/Why-Amartya-Sen-iswrong.html

Bhagwati, J. and A. Panagariya (2013) 'Letters. On India, Gay Marriage, Protesting, Iran, Marc Rich, Political Pi', The Economist 11 July. www.economist.com/news/letters/21581693-india-gay-marriage-protesting-iranmarc-rich-political-pi

Black, R.E. et al. (2013) 'Maternal and Child Undernutrition and Overweight in Low-Income and Middle-Income Countries', The Lancet 382(9890): 427-51.

Chopra, D. (2011a) 'Policy Making in India: A Dynamic Process of Statecraft', Pacific Affairs 84(1): 89-107.

Chopra, D. (2011b) 'Interactions of Powerin the Making and Shaping of Social Policy', Contemporary South Asia 19(2): 153-71.

CNN-IIBN (2013) 'Amartya Sen Should Be Stripped of His Bharat Ratna Says Bjp Mp Chandan Mitra', IBN Live. https://www.youtube.com/watch?v=cy-ddiyYlFg

Coffey, D., A. Deaton, J. Drèze, D. Spears and A. Tarozzi (2013) 'Stunting among Children: Facts and Implications', Economic and Political Weekly 48(34): 69.

Dasgupta, P. (2013) 'Getting India Wrong', Prospect 25 July. www.prospectmagazine.co.uk/magazine/partha-dasgupta-amartya-sen-review-gdpwealth-development-economics-getting-india-wrong

Deaton, A. (2013) 'Book. What's Going on in India', The Lancet 382: 1015-. 
Deaton, A. and J. Drèze (2009) 'Food and Nutrition in India: Facts and Interpretations', Economic and Political Weekly 44(7): 42-65.

Deaton, A. and J. Drèze (2010) 'Nutrition, Poverty and Calorie Fundamentalism: Response to Utsa Patnaik', Economic and Political Weekly 45(14): 78-80.

Derbyshire, J. (2013) 'Prospect Interviews Amartya Sen (the Full Transcript)', Prospect 18 July. www.prospectmagazine.co.uk/magazine/prospect-interviews-amartya-sen-thefull-transcript-jonathan-derbyshire

Dodge, J., S.M. Ospina and E.G. Foldy (2005) 'Integrating Rigor and Relevance in Public Administration Scholarship: The Contribution of Narrative Inquiry', Public Administration Review 65(3): 286-300.

Dreze, J. and A. Sen (1989) Hunger and Public Action. Oxford: Oxford University Press.

Dreze, J. and A. Sen (2013) An Uncertain Glory: India and its Contradictions. London: Allen Lane.

Feldman, M.S., K. Sköldberg, R.N. Brown and D. Horner (2004) 'Making Sense of Stories: A Rhetorical Approach to Narrative Analysis', Journal of Public Administration Research and Theory 14(2): 147-70.

Ferguson, J. (1994) The Anti-Politics Machine: Development, Depoliticization and Bureaucratic Power in Lesotho. Minneapolis, MN: University of Minnesota Press.

Gardner, K. and D. Lewis (2015) Anthropology and Development: Challenges for the Twenty-First Century. London: Pluto Press.

Ghosh, A., A. Gupta and D. Spears (2014) 'Are Children in West Bengal Shorter Than Children in Bangladesh?', Economic and Political Weekly 49(8):21-24

Gillespie, S. (2013) 'Myths and Realities of Child Nutrition', Economic and Political Weekly 48(34): 64-7.

Goldman, M. (2005) Imperial Nature: The World Bank and Struggles for Social Justice in the Age of Globalization. New Haven, CT: Yale University Press.

Government of India (2007) 'Text of Prime Minister's Independence Day Address'. Press Release, Press Information Bureau Prime Minister's Office, 15 August 2007.

Government of India (2012) 'PM's Speech at the release of HUNGaMA (Hunger and Malnutrition) Report' Press Release, Press Information Bureau, Prime Minister's Office, 10 January 2012. http://pib.nic.in/newsite/PrintRelease.aspx?relid=79457 Government of India and UNICEF (2016) Rapid Survey on Children (RSOC) 2013-14. National Report 
http://wcd.nic.in/sites/default/files/RSOC\%20National\%20Report\%20201314\%20Final.pdf

Guest, G., A. Bunce and L. Johnson (2006) 'How Many Interviews Are Enough? An Experiment with Data Saturation and Variability', Field Methods 18(1): 59-82.

Gupta, A. et al. (2013) ‘Are Child Malnutrition Figures for India Exaggerated?', Economic and Political Weekly 48(34): 73.

IFPRI (2015) Global Nutrition Report 2015: Actions and Accountability to Advance Nutrition and Sustainable Development. Washington, DC: International Food Policy Research Institute.

Jain, A. (2012) 'Failure to Meet Who Standard Is Attributed to Malnutrition', tehelka.com. www.tehelka.com/2012/11/once-we-do-our-malnutrition-numbers-correctly-we-willfind-that-india-has-no-more-to-be-ashamed-of-its-malnutrition-level/

Jayachandran, S. and R. Pande (2013) 'Choice Not Genes', Economic and Political Weekly, 48(34): 71-3.

Jones, M.D. and M.K. Mcbeth (2010) 'A Narrative Policy Framework: Clear Enough to Be Wrong?', The Policy Studies Journal 38(2): 329-53.

Khera, R. (2011) The Battle for Employment Guarantee, Oxford: Oxford University Press.

Kimura, A.H. (2013) Hidden Hunger. Gender and the Politics of Smarter Foods. Ithaca, NY: Cornell University Press.

Lamont, J. (2010) 'Nobel Laureate Attacks India’s Growth Fixation', The Financial Times. www.ft.com/content/554eab3e-0d33-11e0-82ff-00144feabdc0

Leach, M. and I. Scoones (2013) 'The Social and Political Lives of Zoonotic Disease Models: Narratives, Science and Policy', Social Science and Medicine 88: 10-17.

Livemint (2013) 'A Nutritional Crisis in India', Mint. www.livemint.com/Opinion/vqYvLzUrAbmPJ66WRQxtEO/A-nutritional-crisis-inIndia.html

Lodha, R., Y. Jain and C. Sathyamala (2013) 'Reality of Higher Malnutrition among Indian Children', Economic and Political Weekly 18(34): 70-3.

Mcbeth, M., E.A. Shanahan, R.J. Arnell and P.L. Hathaway (2007) 'The Intersection of Narrative Policy Analysis and Policy Change Theory', The Policy Studies Journal, 35(1): 87-108.

Mishra, P. (2013) 'Which India Matters?', The New York Review of Books 21 November. www.nybooks.com/articles/2013/11/21/which-india-matters/ 
Mosse, D. (2004) Cultivating Development: An Ethnography of Aid Policy and Practice London: Pluto Press.

Naandi Foundation (2011) HUNGaMA. Fighting Hunger and Malnutrition. The HUNGaMA Survey Report. http://www.hungamaforchange.org/HungamaBKDec11LR.pdf

O’Reilly, M. and N. Parker (2012) “'Unsatisfactory Saturation': A Critical Exploration of the Notion of Saturated Sample Sizes in Qualitative Research', Qualitative Research. DOI: $10.1177 / 1468794112446106$.

Panagariya, A. (2011) 'The Child Malnutrition Myth', The Times of India 1 October. http://timesofindia.indiatimes.com/edit-page/The-child-malnutritionmyth/articleshow/10188187.cms

Panagariya, A. (2012) 'The Myth of Child Malnutrition in India'. Paper presented at the conference India: Reforms, Economic Transformation and the Socially Disadvantaged, held at Columbia University, New York (20-22 September).

Patel, R., R. Bezner Kerr, L. Shumba and L. Dakishoni (2015) 'Cook, Eat, Man, Woman: Understanding the New Alliance for Food Security and Nutrition, Nutritionism and Its Alternatives from Malawi’, Journal of Peasant Studies 42(1): 21-44.

Patnaik, U. (2010a) 'A Critical Look at Some Propositions on Consumption and Poverty', Economic and Political Weekly 45(6): 74-80.

Patnaik, U. (2010b) 'On Some Fatal Fallacies', Economic and Political Weekly 45(47): 81-7.

Rabinow, P. (1991) The Foucault Reader: An Introduction to Foucault's Thought. London: Penguin Books.

Rajadhyaksha, N. (2013) 'Gandhi vs Modi is Actually Sen vs Bhagwati’, Mint. www.livemint.com/Politics/LKb8rZi6t6t7TRYOVKKKyH/Gandhi-vs-Modi-isactually-Sen-vs-Bhagwati.html

Riessman, C. (2008) Narrative Methods for the Human Sciences. London: Sage.

Roe, E. (1989) 'Narrative Analysis for the Policy Analyst: A Case Study of the 1980-1982 Medfly Controversy in California', Journal of Policy Analysis and Management 8(2): 251-73.

Roe, E. (1994) Narrative Policy Analysis: Theory and Practice. Durham, NC: Duke University Press.

Sen, A. (2013a) 'Letters. On Amartya Sen, Defence Spending, Britain, Egypt, Immigration, France, GDP, Sailing', The Economist 20 July. www.economist.com/news/letters/21581963-amartya-sen-defence-spending-britainegypt-immigration-france-gdp-sailing 
Sen, A. (2013b) 'Why India Trails China', The New York Times 20 June. www.nytimes.com/2013/06/20/opinion/why-india-trails-china.html

Sen, A. and J. Dreze (2011) 'Putting Growth in Its Place', Outlook 14 November. www.outlookindia.com/magazine/story/putting-growth-in-its-place/278843

Shanahan, E.A., M.D. Jones, M.K. Mcbeth and R.R. Lane (2013) 'An Angel on the Wind: How Heroic Policy Narratives Shape Policy Realities', The Policy Studies Journal 41(3): 453-83.

Sharma, M.S. (2012) 'Lunch with BS:Arvind Panagariya', Business Standard 31 July. www.business-standard.com/article/opinion/lunch-with-bs-arvind-panagariya112073100025 1.html

Stone, D. (2002) Policy Paradox: The Art of Political Decision Making. New York and London: Norton.

Ullekh, N.P. (2013) 'I Was Taken Back by Professor Amartya Sen’s Comments on Food Bill: Arvind Panagariya', The Economic Times 17 May. http://economictimes.indiatimes.com/opinion/interviews/i-was-taken-aback-byprofessor-amartya-sens-comments-on-food-bill-arvindpanagariya/articleshow/20103644.cms

Wable, G. (2013) 'Methodologically Deficient, Ignorant of Prior Research', Economic and Political Weekly 48(34): 60-64.

WHO (2014) 'Global Nutrition Targets 2025'. WHO Stunting Policy Brief. www.who.int/nutrition/publications/globaltargets2025_policybrief_stunting/en/

Nicholas Nisbett (n.nisbett@ids.ac.uk) is a Senior Research Fellow at IDS, where he studies the political economy of nutrition policy and programming at national and community levels. He has also published a monograph on youth aspirations in the field of Indian IT use and employment, titled Growing up in the Knowledge Society: Living the IT Dream in Bangalore (Routledge, 2010). 